\title{
Relation between clinical, histopathological properties and microvessel density assessed by CD105 and CD31 in prostate carcinoma
}

\section{Prostat karsinomunda CD105 ve CD31 ile araștırılan mikrovasküler yoğunluğun klinik ve histopatolojik bulgularla ilişkisi}

\author{
Egemen Akıncıoğlu' ${ }^{1}$, İlke Evrim Seçinti ${ }^{2}$, Olcay Kandemir ${ }^{3}$, Ege Can Şerefoğlu ${ }^{4}$ \\ ${ }^{1}$ Department Of Pathology, Ufuk University, Ankara, Turkey \\ ${ }^{2}$ Deparment Of Pathology, Silifke State Hospital, Mersin, Turkey \\ ${ }^{3}$ Department Of Pathology, Ankara Oncology Training And Research Hospital, Ankara, Turkey \\ ${ }^{4}$ Department Of Urology, Bagcilar Training And Research Hospital, İstanbul, Turkey
}

\section{ÖZET}

Giriş ve Amaç: Bu çalışmayı, prostat kanserinde, tümör dokusunda ve tümör çevresinde CD105 ve CD31 ile araştırılan mikrovasküler yoğunluğun (MVY) histopatolojik ve klinik bulgularla ilişkisini araştırmak amacıyla planladik.

Yöntem ve Gereçler: Çalışmamızda, Patoloji Bölümünde incelenmiş 100 radikal prostatektomi materyali klinik ve histopatolojik bulguları açısından retrospektif olarak değerlendirildi. Her bir materyaldeki tümör dokusuna ve tümör çevresine CD105 ve CD31 immünohistokimyasal belirteçleri uygulandı. Tümoral ve peritümöral CD105 ve CD31 ile MVY ekspresyonu, klinik ve histopatolojik bulgularla karşılaştırıldı.

Bulgular: Tümör dokusunda CD105 ve CD31 ile MVY, tümör çevresindekinden anlamlı olarak fazla bulundu $(\mathrm{p}<0.001)$. Tümör çevresindeki CD105 ile boyanan damar sayısı, tümör çevresindeki CD31 ile boyanan damar sayısından anlamlı derecede düşük bulundu $(\mathrm{p}<0.001)$. Tümör dokusundaki CD105 MVY ile preoperatif serum total PSA düzeyi, tümör hacmi, perinöral invazyon, lenf düğ̈̈mü metastazı ve lokal invazyon arasında anlamlı ilişki bulundu (sırasıyla $\mathrm{r}=0,338$ ve $\mathrm{p}<0,001, \mathrm{p}=0,003, \mathrm{p}=0,009, \mathrm{p}=0,044$ ). Tümör dokusundaki CD31 MVY ekspresyonu ile patolojik evre, cerrahi sınırda tümör bulunması ve veziküloseminalis invazyonu arasında anlamlı ilişki bulundu (sırasıyla $\mathrm{r}=0,228$ ve $\mathrm{p}=0,022, \mathrm{p}=0,034$ ). Tümör çevresindeki CD105 ve CD31 MVY ekspresyonu ile klinik ve histopatolojik bulgular arasında anlamlı ilişki görülmedi ( $\mathrm{p}>0,05)$.

Tartışma ve Sonuç: Tümör dokusundaki CD105 ve CD31 MVY'nun, prognostik açıdan önemli klinik bulgularla ilişkili olması, tümör pogresyonunda anjiogenezin önemini vurgulamaktadır. Bu bulgu anti-anjiojenik ajanları içeren yeni tedavi modalitelerinin gelişmesini sağlayacaktır.

Anahtar Kelimeler: Prostat kanseri, CD31 Antijeni, CD105 Antijeni, Mikrovasküler yoğunluk

\section{ABSTRACT}

Introduction: We designed this study in order to investigate the relation between histopathological and clinical properties in prostatic carcinoma patients and microvessel density (MVD) of tumoral and peritumoral tissue, assessed by CD105 and CD31 expression.

Methods: A total of 100 radical prostatectomy samples, have been evaluated retrospectively with clinical and histopathological findings. Immunohistochemical markers of CD105 and CD31 were applied to the tumoral tissue and surroundings of tumor. Relation between tumoral and peritumoral CD105, CD31 and clinical or histopathological findings was evaluated.

Results: CD105 and CD31 together with MVD have been found more significant in the tumoral tissue than the periphery $(p<0,001)$. CD105 expression in the peritumoral tissue was significantly lower than the CD31 expression. A significant correlation has been found between CD105 MVD in the tumoral tissue and the preoperative serum total PSA levels and tumor volume $(\mathrm{r}=0.259, \mathrm{p}=0.009, \mathrm{r}=0.198, \mathrm{p}=0.049$, respectively). Tumoral CD105 expression was significantly higher in cases with perineural invasion, lymph node metastasis and local invasion $(\mathrm{p}=0.003, \mathrm{p}=0.009, \mathrm{p}=0.044)$. CD31 expression was significantly correlated with pathological stage $(\mathrm{r}=0.228, \mathrm{p}=0.022, \mathrm{p}=0,034$, respectively). Cases with seminal vesicle invasion and extracapsular extension had with significantly higher CD31 MVD. No significant correlation was found between peritumoral tissue MVD and clinical or histopathological findings.

Discussion and Conclusion: Finding of association between CD105 and CD31 in the tumoral tissue and prognostic clinical findings, supports the importance of angiogenesis in tumoral progression. This may reveal new treatment modalities for research involving anti-angiogenic agents.

Key words: Prostate Cancer, CD31 Antigen, CD105 Antigen; Microvessel density. 


\section{Introduction}

Proliferation of tumor cells as well as the support from adjacent cells are required for the tumor tissue to grow. The formation of new vessels inside the tumor is important (1). The newly formed vessels are more fenestrated and have thinner basement membranes than normal vessels which lead to increased permeability and leakage of tumor cells to the circulation. Therefore, angiogenesis is an important prognostic marker for metastasis of malignencies (2).

Prostate cancer is the third most common malignancy worldwide after lung and stomach cancer (3). The risk of prostate cancer in men of every age is $9.7 \%$ (4). Taking into consideration the importance of angiogenesis; intratumoral microvessel density (MVD) has first been searched in prostate cancer in 1993 by Weidner et al. (5). Evaluation of the correlation between prognostic parameters and angiogenesis is a topic that needs to be searched. Clinical implications of these studies may result in antiangiogenic treatment options, which may reduce morbidity and mortality of patients.

In order to determine the MVD, antibodies such as CD31, CD34, Factor 8, von Willebrand Factor and CD105 have been used $(6,7)$, but there is no consensus about which antibodies are best and should be used primarily. CD105 (endoglin) is a transmembrane glycoprotein, which is expressed by active endothelial cells (8). CD31 is a member of the immunoglobulin gene superfamily, that is expressed on the surface of hematopoietic and immune cells (9). While CD105 stains only vessels associated with tumors, CD31 is expressed in vessels both in normal and malignant tissue. CD105 generally stains lesser or no vessels in peritumoral tissues (8).

We aimed to investigate the relationship of MVD of both tumoral and peritumoral tissues stained by CD105 and CD31 with histopathological and clinical findings in prostate cancer.

\section{Materials and Method}

For this retrospective study; samples of the patients who had undergone radical prostatectomy with the diagnosis of prostatic cancer from January 2006 to December 2008 in a research hospital, were examined. Patients who received neoadjuvant radiotherapy or hormonal therapy before surgery, were excluded. Age, preoperative serum total PSA levels and local invasion findings were recorded. Hematoxylin-Eosin stained slides were reevaluated in terms of Gleason grade, tumor volume, extracapsular extension, perineural invasion, seminal vesicle invasion, pathological tumor stage and lymph node metastasis. The pathological stage was determined by using the TNM system, which has been prepared by the 'American Joint Committee on Cancer (AJCC)' and the 'International Union Against Cancer (UICC)' in the year 2002.

The region with highest Gleason score was accepted as tumoral region. CD105 (Endoglin, TGF beta 1/3 receptor): Rabbit polyclonal antibody, $200 \mu \mathrm{g} / \mathrm{ml}$ (Thermo Scientific), 1/25 dilution and CD31 (PECAM1, Ab-1): Mouse antibody, klon JC/70A (Thermo Scientific), 1/100 dilution antibodies were applied. Tissues of third trimester placentas (syncytiotrophoblast and vascular endothelial cells) and tonsillar tissues (vascular endothelial cells) were used as a control for CD105 and for CD31, respectively.

The slides were evaluated with a light microscope (Olympus, CX31). In order to determine the MVD, the hot spot method was used (5). Areas with the most intense capillaries and small venules inside the tumor tissue and tumor surroundings were determined with small magnification ( $\mathrm{x} 40$ and $\mathrm{x} 100$ ) and we counted four different areas with big magnification $(\mathrm{x} 400)$. Brown stained endothelial cells or endothelial cell clusters, that could be separated from the environmental connective tissue or tumor cells, were evaluated disregarding the presence of lumen.

Statistical Analysis: For the analysis of the data the program SPSS 11.5 for Windows was used. Whether the distributions of continuous variables were normally or not was determined by Shapiro Wilk test. While nominal data was shown as number of cases and percentage, mean \pm SD or median (min$\max$ ) were used for continuous variables. The differences of tumor volume, gleason score, CD105 and CD31 between the groups, were assessed by Mann Whitney U test. Whether there is a statistical difference within the 
number of vessels stained with CD105 and CD31 and the values in the tumor tissue and tumor surroundings, was evaluated by Wilcoxon sign test. Degrees of association between continuous variables were evaluated by Spearman's Rank Correlation analyses. A p value less than 0.05 was considered statistically significant.

\section{Results}

In this study we evaluated 100 prostatic cancer patients who meet the criteria. Clinical and histopathological findings of the patients are summarized in Table 1. The mean number of blood vessels showing positive immunoreactivity with CD105 and with CD31 in tumor tissue was $49.29 \pm 22.31$ and $51.56 \pm$ 26.45 respectively whereas the median blood vessel counts were $46(15-128)$ and $49(0-$ 146). The mean number of blood vessels in peritumoral tissue stained with CD105 and CD31 was $26.25 \pm 9.39$ and $34.15 \pm 14.55$. The median counts of CD 105 and CD31 were $25.5(0-53)$ and $30.0(0-73)$ in peritumoral tissues. Three cases showed no staining with CD31 inside the tumor tissue but staining in peritumoral tissue whereas one case showed only tumoral staining. One case showed no staining inside the tumor tissue but staining in peritumoral tissue with CD105. Although there was no significant difference between the MVD of two antibodies in tumoral tissues ( $p=0.527)$; the number of vessels stained with $\mathrm{CD} 105$ in the peritumoral tissue were significantly lower than CD31 ( $<<0,001)$. MVD assessed by CD 105 and CD31 in tumoral tissue was significantly higher than MVD in the peritumoral tissues $(p<0.001$ and $\mathrm{p}<0.001)$.

Within the histopathological properties tumors with perineural invasion, lymph node metastasis and local invasion showed a significantly higher CD105 staining when compared to the cases without these properties $(\mathrm{p}=0.003, \mathrm{p}=0.009, \mathrm{p}=0.044$, respectively) (Table 2). CD105 staining showed a statistically significant correlation with the preoperative serum total PSA level and the tumor volume $(\mathrm{r}=0.259, \mathrm{p}=0.009 ; \mathrm{r}=0.198$, $\mathrm{p}=0.049)$. No significant correlation between the CD105 expression and the other characteristics was found. Significant correlation was found between the number of
Table 1. Clinical and histopathological findings of the patients

\begin{tabular}{|ll|}
\hline & No $(\%)$ \\
Mean \pm SD Age (range) & $64,94 \pm 5,99$ \\
Preoperatif serum total & \\
$0-2,5$ & $3(3)$ \\
$2,5-10$ & $52(2)$ \\
$>10$ & $45(45)$ \\
Mean \pm SD tumor & $9,84 \pm 17,29$ \\
$<5$ & 61 \\
$5-15$ & 20 \\
15-25 & 9 \\
$\geq 25$ & 10 \\
Pathological Stage & \\
PT2a & $17(17)$ \\
PT2b & $16(16)$ \\
PT2c & $41(41)$ \\
PT3a & $11(11)$ \\
PT3b & $12(12)$ \\
PT4 & $3(3)$ \\
Extracapsular Extension & \\
Present & 71 \\
Absent & 29 \\
Perineural Invasion & \\
Present & 74 \\
Absent & \\
Invasion of the Seminal & \\
Present & \\
Absent & \\
Lymph Node Metastasis & \\
Present & \\
Absent & \\
\hline
\end{tabular}

vessels in tumoral tissue stained with CD31 and the pathological stage $(r=0.228$, $\mathrm{p}=0.022)$. The number of blood vessels in 
Table 2: Correlation of CD105 MVD with Histopathological Findings

\begin{tabular}{|l|l|l|l|l|l|l|l|}
\hline \multicolumn{2}{|c|}{} & $\begin{array}{l}\text { Number } \\
\text { of Cases }\end{array}$ & $\begin{array}{l}\text { Average } \\
\text { MVD. }\end{array}$ & $\begin{array}{l}\text { Standard } \\
\text { Deviation }\end{array}$ & $\begin{array}{l}\text { Median } \\
\text { MVD }\end{array}$ & $\begin{array}{l}\text { Minimum } \\
\text { MVD }\end{array}$ & $\begin{array}{l}\text { Maximum } \\
\text { MVD }\end{array}$ \\
\hline \multirow{2}{*}{$\begin{array}{l}\text { Perineural } \\
\text { Invasion }\end{array}$} & Present & 74 & 52,47 & 22,18 & 50 & 15 & 128 \\
\cline { 2 - 8 } Lymph Node & N/A & 26 & 40,23 & 20,45 & 36 & 16 & 101 \\
\cline { 2 - 8 } & Metastatic & 7 & 67,14 & 16,6 & 65 & 50 & 101 \\
\hline \multirow{2}{*}{$\begin{array}{l}\text { Local } \\
\text { Invasion }\end{array}$} & Present & 93 & 47,94 & 22,17 & 44 & 15 & 128 \\
\cline { 2 - 8 } & N/A & 97 & 67,66 & 3,78 & 66 & 65 & 72 \\
\hline
\end{tabular}

Table 3: Correlation of CD31 with Histopathological Findings

\begin{tabular}{|l|l|l|l|l|l|l|l|}
\hline \multicolumn{2}{|c|}{} & $\begin{array}{l}\text { Number } \\
\text { of Cases }\end{array}$ & $\begin{array}{l}\text { Average } \\
\text { MVD. }\end{array}$ & $\begin{array}{l}\text { Standard } \\
\text { Deviation }\end{array}$ & $\begin{array}{l}\text { Median } \\
\text { MVD }\end{array}$ & $\begin{array}{l}\text { Minimum } \\
\text { MVD }\end{array}$ & $\begin{array}{l}\text { Maximum } \\
\text { MVD }\end{array}$ \\
\hline $\begin{array}{l}\text { Seminal } \\
\text { Vesicle } \\
\text { Invasion }\end{array}$ & Present & 15 & 68,66 & 36,2 & 61 & 26 & 146 \\
\cline { 2 - 8 } & N/A & 85 & 48,54 & 23,34 & 48 & 0 & 122 \\
\hline
\end{tabular}

tumoral tissue stained with CD31 was significantly higher in cases with seminal vesicle invasion and extracapsular extension ( $\mathrm{p}=0.034$ and $\mathrm{p}=0.048$ ) (Table 3). There was no significant correlation between CD31-MVD in tumoral tissue and age, preoperative serum total PSA levels, tumor volume, Gleason score, perineural invasion, lymph node metastasis and local invasion ( $p>0.05)$. CD105 and CD31MVD in the periphery was not correlated with clinical and histopathological findings.

\section{Discussion}

This study investigated the CD105 and CD31 antibodies and MVD inside the tumor and in the periphery. For both antibodies, the expression was higher inside the tumor compared to the periphery, which supports the presence of increased vascularity inside the prostatic carcinomas.

A number of studies have been carried out to identify the prognostic significance of MVD in prostate cancer. Divergent data about the relation between MVD and clinicopathological parameters in prostate cancer exists. Various antibodies were found to be associated with prognostic factors in some of the studies while some of the studies support the opposing opinions. Miyata et al. explained the reason for this discrepancy with different methodology of measuring MVD in cancers (10). In order to determine the MVD in our study, the hot spot method of Weidner et al., has been used (5). Weidner at al. and Bono et al. evaluated the MVD with a magnification of 200 . $(5,11)$. In order to increase accuracy and the counted areas, we evaluated the MVD with the same method but with a magnification of 400 and in four different areas.

In the literature, different antibodies were searched for MVD in prostate cancer. In one study the Factor 8 associated antigen was assessed in 98 prostate cancers, 5 prostate adenomas and 20 normal prostate tissues in order to compare the MVDs (12). The MVD in prostatic cancer has been found higher than MVD in prostate adenoma and normal prostate tissue (12). Kaygusuz et al. (13) reported that angiogenesis mediators such as Vascular Endothelial Growth Factor (VEGF), p53 and

Thrombospondin-1 (TSP-1) were expressed more in prostatic tumors than normal prostate tissue unlike basic Fibroblast Growth Factor (bFGF) which did not differ in tumors. A prostate core biopsy study reported an association with the pathological stage and MVD in prostatectomy specimens (14). They also reported that it would be possible to guess the pathological stage by looking at the MVD in core biopsy (14).

While CD31 stains vessels both associated with tumors and normal tissues, CD105 is more specific to proliferating vessels in tumoral tissues (8). Our study showed that the CD105-MVD in the peritumoral tissue was lower than the CD31-MVD. These findings support that CD105 could be a potential indicator for proliferating epithelium. Moreover, CD105 staining was observed significantly lower after neoadjuvant hormonal therapy (NHT), whereas many CD31 and CD34 positively stained vessels were observed in degenerate area of cancer tissues in patients with NHT (7). As we excluded the patients 
who had neoadjuvant therapy, we can't make a comment on the effect of therapies on MVD and relation with immunohistochemical agents. There are studies reporting lack of CD31 expression in some of the tumors $(2,15)$ as we also observed in three cases. But CD105 stained the tumor tissue in all of the samples.

The serum PSA level is an important tumor marker used in the diagnosis and followup of prostate cancer (16). From the clinicopathological parameters searched, we found a positive correlation between preoperative serum total PSA and CD105MVD inside the tumor tissue. Similarly, ElGohary et al. reported the same correlation between MVD detected by CD105 in prostate tumors and the preoperative serum total PSA level in their study (2). Also finding of higher CD105 staining in tumors with perineural invasion, lymph node metastasis and local invasion compared to the cases without these properties support the prognostic significance of CD105-MVD. Other studies also reported an association between CD105 and Gleason score, the local tumor stage and metastasis (2, 17).

Regarding CD31-MVD, Silberman et al. found out that cases with a Gleason score of 5-7, MVD, determined via CD31, is related to the progression of the disease (18). Another study however reported that CD31 does not provide additional information with respect to Gleason score and pathological stage in terms of disease progression evaluation (19). In the study that compared CD31 and MVD of needle biopsy and radical prostatectomy material of 61 cases, a correlation between microvessel density, pathological stage and the Gleason score has been found (20). We found that CD31-MVD was significantly associated with seminal vesicle invasion, extracapsular extension and the pathological stage.

As a conclusion, we found higher MVD in tumoral tissue compared to peritumoral region. Staining with CD105 and CD31 in the prostatic carcinomas is related to the some of the clinicopathological properties of patients and this finding makes these markers promising markers for future treatment modalities.

Acknowledgements: Surgical procedures were performed by M.F.K.., R.O., G.T., A.T.T. and N.B.. M.K., I.U., and N.B collected data and performed the analysis and the interpretation of data. Manuscript preparation was performed by M.F.K., M.K., and G.K. Drafting the article or revising it critically for important intellectual content was performed by all authors. All authors have approved the final version of the manuscript. No financial funding exists in preparing the manuscript or acquiring data.

\section{Conflict of interest: None}

\section{Kaynaklar}

1. Weidner $\mathrm{N}$. The importance of the tumor angiogenesis, Am J Clin Pathol. 2004;122:675-7

2. El- Gohary YM, Silverman JF, Olson PR, Liu YL, Cohen JK, Miller R. Endoglin (CD105) and vascular endothelial growth factor as prognostic markers in prostatic adenocarcinoma. Am J Clin Pathol. 2007;127(4):572-9

3. Humphrey PA. Prostate Gland Development and Anatomic Structure. Humphrey PA. Prostate Pathology. American Society for Clinical Pathology: Chicago, 2003:3-29

4. Epstein JI, Algaba F, Allsbrook WC, Bastacky S, Boccon-Gibod L, De Marzo AM . Tumours of the Urinary System and Male Genital Organs. World Health Organization Classification of Tumours International Agency for Research on Cancer (IARC): Lyon, 2004:158-92

5. Weidner N, Carroll P, Flax J, Blumenfeld W, Folkman $\mathrm{J}$. Tumor angiogenesis correlates with metastasis in invasive prostate carcinoma. Am $\mathrm{J}$ Pathol. 1993;143:401-9

6. Rubin MA, Buyyounouski M, Bagiella E, Sharir S, Neugut A, Benson M. Microvessel density in prostate cancer: lack of correlation with tumor grade, pathologic stage and clinical outcome. Urology. 1999;53(3):542-7

7. Miyata Y, Mitsunari K, Asai A, Takehara K, Mochizuki Y, Sakai H. Pathological significance and prognostic role of microvessel density, evaluated using CD31, CD34, and CD105 in prostate cancer patients after radical prostatectomy with neoadjuvant therapy. Prostate. 2015;75:84-91

8. Nikolaos AD, Shaija S, Ling X, Fan F, Michael G, Sherry JL. Endoglin (CD105): A Marker of Tumor Vasculature and Potential Target for Therapy. Clin Cancer Res. 2008; 14(7):1931-7

9. Woodfin A, Voisin MB, Nourshargh S. PECAM-1: a multi-functional molecule in inflammation and vascular biology. Arterioscler Thromb Vasc Biol. 2007;27(12):2514-23

10. Miyata Y, Sakai H. Reconsideration of the clinical and histopathological significance of angiogenesis in prostate cancer: Usefulness and limitations of microvessel density measurement. Int $\mathbf{J}$ Urol. 2015;22(9):806-15

11. Bono AV, Celato N, Cova V, Salvadore M, Chinetti S, Novario R. Microvessel density in prostate carcinoma. Prostate Cancer Prostatic Dis. 2002;5(2):123-7 
12. Strohmeyer D, Rössing C, Strauss F, Bauerfeind A, Kaufmann O, Loening S. Tumor angiogenesis is associated with progression after radical prostatectomy in pT2 / pT3 prostate cancer. Prostate. 2000;42(1):26-33

13. Kaygusuz G, Tulunay O, Baltac1 S, Gogus O. Microvessel density and regulators of angiogenesis in malignant and nonmalignant prostate tissue. Int Urol Nephrol. 2007;39(3):841-50

14. Rogastch H, Hittmair A, Reissigl A, Mikuz G, Feichtinger $\mathrm{H}$. Microvessel density in core biopsies of prostatic adenocarcinoma: a stage predictor? J Pathol. 1997;182(2):205-10

15. Giatromanolaki A, Sivridis E, Koukourakis MI, Georgoulias V, Gatter KC, Harris AL. Intratumoral angiogenesis: a new prognostic indicator for stage I endometrial adenocarcinomas? Oncol Res. 1999;11(4):205-12

16. Oesterling JE. Prostate spesific antigen: a critical assessment of the most useful tumor marker for adenocarcinoma of the prostate. J Urol. 1991;145(5):907-23

17. Wikström P, Lissbrant IF, Stattin P, Egevad L, Bergh A. Endoglin (CD105) is expressed on immature blood vessels and is a marker for survival in prostate cancer. Prostate. 2002;51(4):268-75

18. Silberman MA, Partin AW, Veltri RW, Epstein JI. Tumor angiogenesis correlates with progression after radical prostatectomy but not with pathologic stage in Gleason sum 5 to 7 adenocarcinoma of the prostate. Cancer. 1997;79(4):772-9

19. Acar C, Sözen S, Erdem Ö, Gürocak S, Yılmaz G, Bozkırlı İ. Prostat kanserinde mikrodamar yoğunluğu, Ki-67 ve P53 ekspresyonu ile klinikopatolojik ölçütler ve hasta prognozu arasındaki ilişki. Türk Üroloji Dergisi. 2006;32(4):478-85

20. Dugonjic AS, Usaj SK, Eri Z, Latinovic LT. Significance of microvessel density in prostate cancer cor biopsy. Vojnosanit Pregl. 2015;72(4):317-27 